\title{
Persepsi Kualitas Sebagai Mediator Antara Merek, Desain, Harga \\ dan Niat Beli Sepeda Motor
}

by

\author{
I Made Widya Suraputra ${ }^{(1)}$ \\ Ida Bagus Raka Suardana ${ }^{(2)}$
}

\author{
Universitas Pendidikan Nasional ${ }^{(1)}$ \\ Universitas Pendidikan Nasional ${ }^{(2)}$ \\ suraputra28@yahoo.com ${ }^{(1)}$ \\ ajikraka@yahoo.com ${ }^{(2)}$
}

\begin{abstract}
This study examines the factors that influence purchase intention, with brand variables, design and price as independent variables and perceived quality as mediating variables. The purpose of this study is to find out how the influence of brand, design, price and quality perception on motorbike intention to buy in Denpasar City.

Data collection techniques used were interviews, observation and questionnaires. The population used in this study is the people of Denpasar City. The number of samples taken was 100 respondents using the Non-Probability Sampling technique, namely accidental sampling. The data analysis technique used is the SEM analysis technique with the Partial Least Square (PLS) method and the SmartPLS 2.0 M3 program tool.

The analysis results show that the purchase intention variable is influenced by brand variables, design and price, and the perception of quality as a mediating variable is also able to strengthen the influence of independent variables on the dependent variable. This study concluded that the brand, design and price directly and indirectly through perceived quality have a positive and significant effect on purchase intention. This research is useful for motorcycle manufacturers in the Denpasar City area to find out consumer behavior towards motorcycle products offered so that they can increase their sales. The limitations of variables and narrow areas will influence the results of the study, therefore further research can better complement these deficiencies.
\end{abstract}

Keywords: Brand, design, price, perceived quality, purchase intention. 


\begin{abstract}
ABSTRAK
Penelitian ini meneliti tentang faktor-faktor yang mempengaruhi niat beli, dengan variable merek, desain dan harga sebagai variable bebas dan persepsi kualitas sebagai variabel mediasi. Tujuan dari penelitian ini untuk mengetahui bagaimana pengaruh merek, desain, harga dan persepsi kuaitas terhadap niat beli sepeda motor di Kota Denpasar.

Teknik pengumulan data yang digunakan adalah wawancara, observasi dan kuisioner. Populasi yang digunakan dalam penelitian ini adalah seluruh masyarakat Kota Denpasar. Jumlah sampel yang diambil adalah sebanyak 100 responden dengan menggunakan teknik Non-Probability Sampling yaitu accidental sampling. Teknik analisis data yang digunakan adalah teknik analisis SEM dengan metode Partial Least Square (PLS) dan alat bantu program SmartPLS 2.0 M3.

Hasil ananlisis menunjukan bahwa variabel niat beli dipengaruhi oleh variabel merek, desain dan harga, serta persepsi kualitas sebagai variabel mediasi juga mampu menguatkan pengaruh variabel bebas terhadap variabel terikat. Penelitian ini berkesimpulan bahwa merek, desain dan harga secara langsung dan tidak langsung melalui persepsi kualitas berpengaruh positif dan signifikan terhadap niat beli. Penelitian ini bermanfaat bagi pihak produsen sepeda motor di wilayah Kota Denpasar untuk mengetahui perilaku konsumen terhadap produk sepeda motor yang ditawarkan sehingga dapat meningkatkan penjualan mereka. Keterbatasan variabel dan wilayah yang sempit akan mempengaruhi hasil penelitian, oleh karena itu penelitian selanjutnya dapat lebih baik melengkapi kekurangan tersebut.
\end{abstract}

Kata Kunci: Merek, desain, harga, persepsi kualitas, niat beli. 


\section{PENDAHULUAN}

Industri otomotif di Indonesia berkembang begitu cepat dan setiap tahunnya selalu mengalami peningkatan yang dikarenakan kebutuhan masyarakat terhadap alat transportasi yang memadai. Dalam menjalani aktivitas sehari-hari untuk berpindah dari satu tempat ke tempat lain, masyarakat di Kota Denpasar lebih cendrung memilih alat transportasi sepeda motor. Saat ini trend pengguna sepeda motor di Kota Denpasar meningkat dikarenakan kurangnya sarana transportasi umum dan tingkat kemacetan yang tinggi, maka dari itu masyarakat lebih cendrung menggunakan sepeda motor karena mampu mengatasi kemacetan serta harga yang terjangkau dan lebih hemat bahan bakar. Kusnadi dan Darma (2018) dalam penelitianya menyebutkan bahwa $\mathrm{brand} / \mathrm{merek}$ serta price/harga merupakan atribut produk yang seringkali digunakan oleh konsumen untuk mengevaluasi kualitas produk yang kemudian menimbulkan niat beli untuk produk yang bersangkutan. Demikian pula untuk desain, Agastya (2015) dalam penelitiannya mengatakan desain merupakan unsur yang mempengaruhi suatu perusahaan dalam memenangkan persaingan.

Banyak produsen sepeda motor tanah air terutama yang memiliki jaringan distribusi pemasaran di wilayah Bali memanfaatkan kesempatan ini untuk meningkatkan total penjualan mereka, terdapat beberapa merek sepeda motor yang telah memiliki citra yang baik dimata konsumen diantaranya adalah sepeda motor merek Honda, Yamaha, Suzuki, Kawasaki dan merek lainnya dimana setiap merek tersebut memiliki keunggulan dan kekurangannya masing-masing. persaingan produsen dalam mendapatkan konsumen sangatlah ketat dimana posisi pertama dipimpin oleh produsen sepeda motor merek Honda dengan persentase penjualan tertinggi, yang kemudian Yamaha sebagai kompetitor kedua lalu ada Kawasaki sebagai kompetitor ketiga dan yang terakhir Suzuki diiringi oleh merekmerek lain sebagai kompetitor bawah.

Berdasarkan fenomena bisnis tersebut maka peneliti tertarik untuk mengkaji lebih dalam lagi tentang peran persepsi kualitas sebagai mediator pengaruh antara merek, desain, dan harga terhadap niat beli sepeda motor. Tujuan dari penenlitian ini adalah untuk mengetahui seberapa besar peran persepsi kualitas dalam memediasi pengaruh merek, desain dan harga terhadap niat beli sepeda motor. 


\section{TINJAUAN PUSTAKA}

\section{Merek}

Kotler \& Keller (2016:322) yang mendefinisikan merek sebagai berikut Merek menandakan tingkat kualitas tertentu sehingga pembeli yang puas dapat dengan mudah memilih produk kembali. Loyalitas merek memberikan tingkat permintaan yang aman perusahaan lain untuk memasuki pasar.

Menurut pendapat Buchari Alma (2013:130) mendefinisikan merek sebagai berikut Merek sebagai suatu tanda atau simbol yang memberikan identitas suatu barang atau jasa tertentu, dapat berupa kata-kata, gambar atau kombinasi keduanya.

Dari definisi-definisi tersebut merek adalah suatu nama, simbol ataupun gabungan diantaranya untuk digunakan sebagai identitas organisasi maupun perusahaan pada barang dan jasa yang berguna untuk membedakan dengan produk dan jasa lainnya. Herlambang (2016) mengemukakan terdapat empat indikator merek diantaranya adalah jaminan kualitas, kepercayaan dan mengekspresikan diri.

\section{Desain}

Desain produk merupakan bagian terpenting dalam merancang suatu bentuk produk sehingga memiliki nilai dan kegunaan untuk memenuhi keinginan konsumen yang disesuaikan dengan perkembangan zaman dan waktu yang berubah-ubah. Menurut Kotler (2016), Setyawati dan Darma (2018) desain adalah ciri-ciri, mutu, kesesuaian dan model dari suatu produk yang nantinya diterima oleh konsumen.

Dari definisi-definisi tersebut desain adalah suatu bentuk maupun konsep yang di ciptakan melalui ide-ide dan pengembangan yang mengarah kepada suatu produk demi menjamin kepuasan pelanggan. Herlambang (2016) mengemukakan terdapat empat indikator desain diantaranya, warna yang menarik, teknologi yang dikembangkan, kemudahan perbaikan dan model terbaru.

\section{Harga}

Menurut Darma (2019) harga adalah sejumlah uang yang dibebankan atas suatu barang atau jasa atau jumlah dari nilai uang yang ditukar konsumen atas manfaat - manfaat karena memiliki atau menggunakan produk atau jasa tersebut.

Menurut Philip Kotler (2013:132): Harga adalah jumlah uang yang harus dibayar pelanggan untuk produk itu. Oh (2014), harga didefinisikan sebagai sesuatu yang diberikan untuk mendapatkan suatu produk.

Dari definisi-definisi tersebut Harga adalah seluruh jumlah dari nilai yang ditukarkan oleh seorang konsumen demi mendapatkan dan memuaskan keinginannya 
dengan memiliki ataupun menggunakan barang dan jasa. Kotler dan Armstrong (2012) mengemukakan terdapat tiga indikator harga diantaranya kesesuaian harga, daftar harga produk dan potongan harga khusus.

\section{Persepsi Kualitas}

Alimudin (2013), Kanten dan Darma (2017) dalam penelitiannya mengatakan persepsi terhadap kualitas produk adalah suatu proses yang terjadi dalam diri individu dalam memilih, menafsirkan, mengorganisasikan, menginterprestasikan dan memberikan penilaian terhadap kualitas suatu produk apakah produk tersebut memuaskan atau tidak yang didasarkan pada pengalaman dan pengetahuannya.

Dari definisi-definisi tersebut persepsi kualitas adalah bagaimana seorang konsumen mencerminkan perasaannya terhadap sesuatu, berupa rasa suka ataupun tidak suka terhadap kualitas ataupu keunggulan suatu produk dan jasa. Hanggadika (2010) mengemukakan terdapat tiga indicator persepsi kualitas diantaranya adalah kualitas keseluruhan, kehandalan dan fungsional.

\section{Niat Beli}

Darma (2006) dan Long (2013) niat beli adalah tingkat kemungkinan seseorang dalam membeli produk atau jasa, dan dapat diartikan sebagai intensitas konsumen dalam menerima preferensi produk atau jasa saat melakukan pemilihan produk atau jasa.

Niat beli merupakan pernyataan konsumen yang merefleksikan rencana pembelian sejumlah produk dengan merek tertentu. Pengetahuan akan niat beli sangat diperlukan para pemasar untuk mengetahui minat konsumen di masa mendatang.

Dari definisi-definisi tersebut niat beli adalah sikap seseorang dalam memutuskan keinginan untuk membeli barang atau jasa yang nantinya dapat memuaskan seseorang tersebut. Terdapat empat indikator niat beli diantaranya adalah kecendrungan mencari informasi, membicarakan, mencoba dan ingin memiliki (Utomo, 2013; Maharani dan Darma, 2018) 


\section{Kerangka Pemikiran}

Berdasarkn penelitian terdahulu maka rumusan hipotesis dan kerangka pemikiran penelitian ini dapat digambarkan pada Gambar 1.

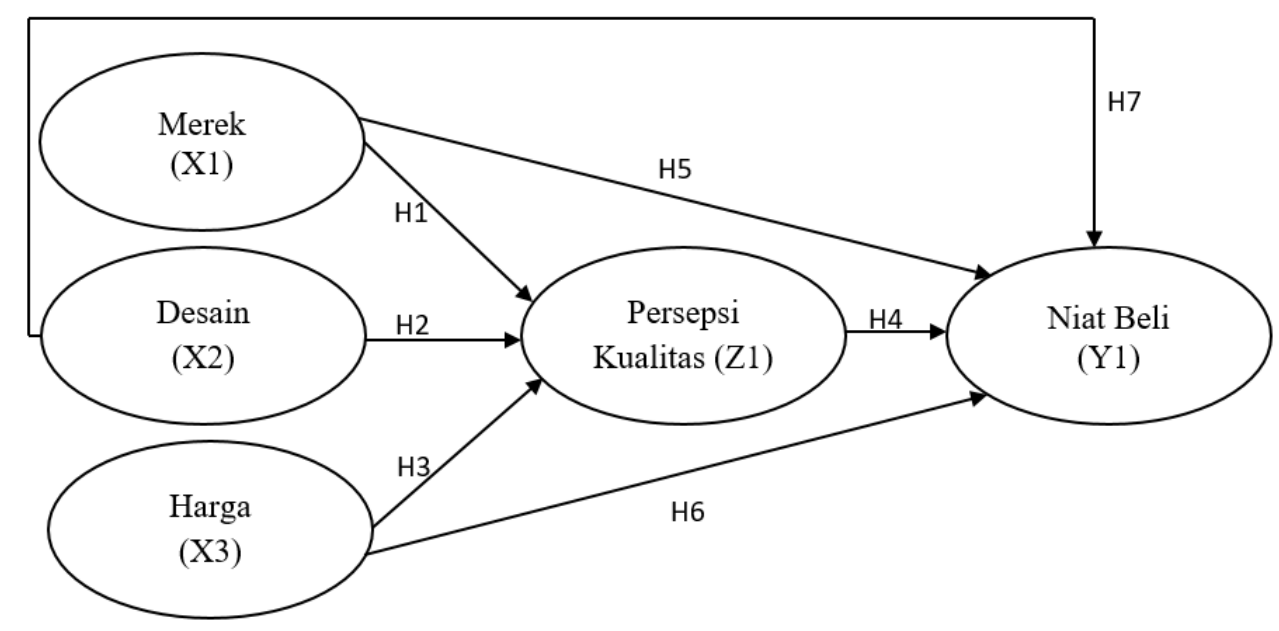

Gambar 1. Kerangka Pemikiran

\section{Hipotesis Penelitian}

H1 : Semakin baik persepsi kualitas memediasi merek suatu produk maka akan meningkatkan niat beli produk tersebut.

H2 : Semakin baik persepsi kualitas memediasi desain suatu produk maka akan meningkatkan niat beli produk tersebut.

H3 : Semakin baik persepsi kualitas memediasi harga suatu produk maka akan meningkatkan niat beli produk tersebut.

H4 : Semakin baik persepsi kualitas terhadap suatu produk, maka akan meningkatkan niat beli produk tersebut.

H5 : Semakin baik merek suatu produk, maka akan meningkatkan niat beli produk tersebut.

H6 : Semakin baik desain suatu produk, maka akan meningkatkan niat beli produk tersebut.

H7 : Semakin baik harga suatu produk, maka akan meningkatkan niat beli produk tersebut. 


\section{METODE PENELITIAN}

Penelitian ini berlokasi di Denpasar, populasi dalam penelitian ini adalah masyarakat Kota Denpasar yang berniat untuk membeli produk sepeda motor, jumlah dari populasi ini adalah infiniti atau tidak terbatas dengan jumlah yang tidak diketahui dengan pasti yaitu masyarakat Kota Denpasar. teknik dalam pengambilan sampel pada penelitian ini adalah dengan menggunakan teknik Non-Probability Sampling dimana setiap anggota populasi memiliki peluang nol. Teknik Non-Probability Sampling yang digunakan dalam penelitian ini adalah Accidental Sampling yaitu berdasarkan ketidak sengajaan atau kebetulan, yaitu setiap orang yang secara kebetulan bertemu dengan peneliti dan sesuai dengan karakteristik responden didalam penelitian maka dapat digunakan sebagai sampel. Mengingat jumlah populasi yang tidak diketahui maka berdasarkan pedoman di atas, sampel ditentukan sebanyak 100 sampel.

Seluruh variabel dalam penelitian ini diukur dengan menggunakan internal scala berbentuk agree disagree scale. Skala ini disusun dalam garis kontinum yang jawaban "sangat setuju" terletak dibagian kanan garis dan jawaban "tidak setuju” terletak dibagian kiri garis dengan rentan jawaban 1 sampai 10 dengan asumsi semakin ke kiri (mendakati angka 1) berarti sangat tidak setuju (STS) dan semakin ke kanan jawaban responden (mendekati angka 10) berarti sangat setuju (SS). Pemilihan skala ini dengan sepuluh tingkat sesuai dengan penelitian empiris sebelumnya, dan bertujuan untuk memperlebar variasi jawaban responden bila dibandingkan dengan penggunaan lima skala agar kecenderungan pemilihan responden terhadap variabel menjadi lebih jelas terlihat.

Pada penelitian ini, penulis menyebarkan 150 kuesioner awal pada responden dan kuesioner yang kembali sebanyak 100 lembar untuk kemudian diuji tingkat validitas dan reliabilitasnya dengan analisis statistik SEM dengan metode Partial Least Square (PLS) dan alat bantu program SmartPLS 2.0 M3. Hasil uji validitas menunjukan korelasi antar skor masing -masing pertanyaan atau koefisien korelasi positif dan lebih besar dai 0,3 maka indikator dikatakan valid. Sementara uji reliabilitas pada 100 kuesioner penelitian ini menunjukkan bahwa kuesioner ini reliable, dengan nilai cronbach's alpha pada masing-masing variabel lebih besar dari 0,60. 


\section{PEMBAHASAN}

Hasil uji validasi koefisien path pada setiap jalur untuk pengaruh langsung dan efek dapat disajikan pada Tabel 1 berikut ini :

Tabel 1

Hasil Pengujian Efek Langsung dan Efek Tanpa Variabel Mediasi

\begin{tabular}{cccc}
\hline Hubungan Antar Variabel & $\begin{array}{c}\text { Koefisien } \\
\text { Jalur }\end{array}$ & $\begin{array}{c}\text { T Statistic } \\
\text { (Bootstrapping) }\end{array}$ & Keterangan \\
\hline Merek (X1) $\rightarrow$ Persepsi kualitas (Z) & 0,214 & 2,413 & Signifikan \\
Merek (X1) $\rightarrow$ Niat beli (Y) & 0,202 & 3,481 & Signifikan \\
Desain (X2) $\rightarrow$ Persepsi kualitas (Z) & 0,245 & 3,507 & Signifikan \\
Desain (X2) $\rightarrow$ Niat beli (Y) & 0,233 & 4,948 & Signifikan \\
Harga (X3) $\rightarrow$ Persepsi kualitas (Z) & 0,537 & 7,388 & Signifikan \\
Harga (X3) $\rightarrow$ Niat beli (Y) & 0,189 & 2,330 & Signifikan \\
Persepsi kualitas (Z) $\rightarrow$ Niat beli (Y) & 0,440 & 4,992 & Signifikan \\
\hline
\end{tabular}

Sumber : data diolah, 2018

\section{Pengaruh merek terhadap persepsi kualitas}

Merek terbukti berpengaruh positif dan signifikan terhadap persepsi kualitas. Hasil ini ditunjukkan oleh koefisien jalur yang bernilai positif sebesar 0,214 dengan t-statistic sebesar 2,413, berdasarkan hasil analisis menunjukkan bahwa merek melalui mediasi persepsi kualitas berpengaruh positif dan signifikan terhadap niat beli sepeda motor di Kota Denpasar. Hal ini memiliki makna bahwa semakin tinggi mediasi persepsi kualitas kepada suatu merek, maka semakin tinggi niat beli konsumen terhadap sepeda motor. Hasil ini sesuai dengan penelitian yang dilakukan oleh Oh (2014) dan Severi dan Ling (2013) yang menyatakan bahwa kualitas produk dirasakan oleh konsumen memiliki hubungan yang positif dan signifikan terhadap merek.

\section{Pengaruh merek terhadap niat beli}

Merek terbukti berpengaruh positif dan signifikan terhadap niat beli. Hasil ini ditunjukkan oleh koefisien jalur yang bernilai positif sebesar 0,202 dengan t-statistic sebesar 3,481, Berdasarkan hasil analisis menunjukkan bahwa persepsi kualitas berpengaruh positif dan signifikan terhadap niat beli sepeda motor di Kota Denpasar. Hal ini memiliki makna bahwa semakin tinggi persepsi kualitas terhadap suatu produk, maka semakin tinggi niat beli konsumen terhadap sepeda motor. Hasil ini sesuai dengan penelitian yang dilakukan oleh Oh (2014) dan Kriswianti (2017) menunjukkan bahwa persepsi kualitas berpengaruh positif dan signifikan terhadap niat beli. 


\section{Pengaruh desain terhadap persepsi kualitas}

Desain terbukti berpengaruh positif dan signifikan terhadap persepsi kualitas. Hasil ini ditunjukkan oleh koefisien jalur yang bernilai positif sebesar 0,245 dengan t-statistic sebesar 3,507 Berdasarkan hasil analisis menunjukkan bahwa desain melalui mediasi persepsi kualitas berpengaruh positif dan signifikan terhadap niat beli sepeda motor di Kota Denpasar. Hal ini memiliki makna bahwa semakin tinggi mediasi persepsi kualitas kepada desain, maka semakin tinggi niat beli konsumen terhadap sepeda motor. Hasil ini sesuai dengan penelitian yang dilakukan oleh Oh (2014) dan Nilforushan dan Haeri (2015) desain suatu produk memiliki efek yang positif dan signifikan terhadap persepsi kualitas konsumen tersebut atas produk yang dilihatnya.

\section{Pengaruh desain terhadap niat beli}

Desain terbukti berpengaruh positif dan signifikan terhadap niat beli. Hasil ini ditunjukkan oleh koefisien jalur yang bernilai positif sebesar 0,233 dengan t-statistic sebesar 4,948, Berdasarkan hasil analisis menunjukkan bahwa desain berpengaruh positif dan signifikan terhadap niat beli sepeda motor di Kota Denpasar. Hal ini memiliki makna bahwa semakin tinggi desain terhadap suatu produk, maka semakin tinggi niat beli konsumen terhadap sepeda motor. Hasil ini sesuai dengan penelitian yang dilakukan oleh Younus, Rasheed dan Zia (2015) dan Herlambang (2016) menyebutkan bahwa desain pada suatu produk memiliki pengaruh positif dan signifikan terhadap niat beli.

\section{Pengaruh harga terhadap persepsi kualitas}

Harga terbukti berpengaruh positif dan signifikan terhadap persepsi kualitas. Hasil ini ditunjukkan oleh koefisien jalur yang bernilai positif sebesar 0,537 dengan t-statistic sebesar 7,388, berdasarkan hasil analisis menunjukkan bahwa harga melalui mediasi persepsi kualitas berpengaruh positif dan signifikan terhadap niat beli sepeda motor di Kota Denpasar. Hal ini memiliki makna bahwa semakin tinggi mediasi persepsi kualitas kepada harga, maka semakin tinggi niat beli konsumen terhadap sepeda motor. Hasil ini sesuai dengan penelitian yang dilakukan oleh Wasis (2013) dan Herlambang (2016) yang menyatakan bahwa harga berpengaruh positif dan signifikan terhadap niat beli melalui mediasi persepsi kualitas.

\section{Pengaruh harga terhadap niat beli}

Harga terbukti berpengaruh positif dan signifikan terhadap niat beli. Hasil ini ditunjukkan oleh koefisien jalur yang bernilai positif sebesar 0,189 dengan t-statistic sebesar 2,330, berdasarkan hasil analisis menunjukkan bahwa harga berpengaruh positif dan signifikan terhadap niat beli sepeda motor di Kota Denpasar. Hal ini memiliki makna 
bahwa semakin baik harga terhadap suatu produk, maka semakin tinggi niat beli konsumen terhadap sepeda motor. Hasil ini sesuai dengan penelitian yang dilakukan oleh Martini (2015) dan Herlambang (2016) menyebutkan bahwa harga memiliki pengaruh yang positif dan signifikan terhadap niat beli.

\section{Persepsi kualitas terhadap niat beli}

Persepsi kualitas terbukti berpengaruh positif dan signifikan terhadap niat beli. Hasil ini ditunjukkan oleh koefisien jalur yang bernilai positif sebesar 0,440 dengan tstatistic sebesar 4,992, Berdasarkan hasil analisis menunjukkan bahwa persepsi kualitas berpengaruh positif dan signifikan terhadap niat beli sepeda motor di Kota Denpasar. Hal ini memiliki makna bahwa semakin tinggi persepsi kualitas terhadap suatu produk, maka semakin tinggi niat beli konsumen terhadap sepeda motor. Hasil ini sesuai dengan penelitian yang dilakukan oleh Oh (2014) dan Kriswianti (2017) menunjukkan bahwa persepsi kualitas berpengaruh positif dan signifikan terhadap niat beli.

\section{PENUTUP}

\section{Kesimpulan}

Berdasarkan pembahasan sebelumnya maka simpulan dari penelitian ini adalah merek melalui mediasi persepsi kualitas berpengaruh positif dan signifikan terhadap niat beli sepeda motor di Kota Denpasar. Hal ini menunjukan bahwa semakin baik persepsi kualitas memediasi merek suatu produk maka akan meningkatkan niat beli terhadap sepeda motor. Desain melalui mediasi persepsi kualitas berpengaruh positif dan signifikan terhadap niat beli sepeda motor di Kota Denpasar. Hal ini menunjukan bahwa semakin baik persepsi kualitas memediasi desain suatu produk maka akan meningkatkan niat beli terhadap sepeda motor. Harga melalui mediasi persepsi kualitas berpengaruh positif dan signifikan terhadap niat beli sepeda motor di Kota Denpasar. Hal ini menunjukan bahwa semakin baik persepsi kualitas memediasi harga suatu produk maka akan meningkatkan niat beli terhadap sepeda motor.

Persepsi kualitas berpengaruh positif dan signifikan terhadap niat beli sepeda motor di Kota Denpasar. Hal ini menunjukan bahwa semakin baik persepsi kualitas terhadap suatu produk, maka semakin tinggi niat beli konsumen terhadap sepeda motor. Merek berpengaruh positif dan signifikan terhadap niat beli sepeda motor di Kota Denpasar. Hal ini menunjukan bahwa semakin baik merek terhadap suatu produk, maka semakin tinggi niat beli konsumen terhadap sepeda motor. Desain berpengaruh positif dan signifikan 
terhadap niat beli sepeda motor di Kota Denpasar. Hal ini menunjukan bahwa semakin baik desain terhadap suatu produk, maka semakin tinggi niat beli konsumen terhadap sepeda motor. Harga berpengaruh positif dan signifikan terhadap niat beli sepeda motor di Kota Denpasar. Hal ini menunjukan bahwa semakin baik harga terhadap suatu produk, maka semakin tinggi niat beli konsumen terhadap sepeda motor.

\section{Saran}

Berdasarkan hasil analisis penelitian, pembahasan dan kesimpulan terdapat beberapa saran yang dapat dipergunakan sebagai bahan pertimbangan dalam menentukan kebijakan dimasa mendatang terutama yang berkaitan dengan merek, desain, harga, persepsi kualitas dan niat beli. Pada variable merek, masyarakat menilai bahwa variabel ini meningkatkan niat beli terhadap sepeda motor. Oleh karena itu setiap merek sepeda motor harus memberikan citra yang baik agar menimbulkan niat beli konsumen. Pada variabel desain, masyarakat menilai bahwa variabel ini meningkatkan niat beli terhadap sepeda motor. Oleh karena itu dalam memproduksi suatu produk sepeda motor, produsen harus memperhatikan perkembangan zaman, kemudian menyesuaikan desain dengan kebutuhan dan permintaan masyarakat. Pada variable harga, masyarakat menilai bahwa variabel ini meningkatkan niat beli terhadap sepeda motor. Oleh karena itu perlu adanya penyesuaian terhadap harga, agar setiap produk sepeda motor yang ditawarkan terjangkau dan sesuai dengan kebutuhan konsumen. Pada variabel persepsi kualitas, masyarakat menilai bahwa variabel ini meningkatkan niat beli terhadap sepeda motor. Oleh karena itu produsen sepeda motor harus menjaga dan meningkatkan kualitas produk yang akan di produksi, agar masyarakat dapat memberikan nilai positif saat melihat produk tersebut.

\section{Implikasi Penelitian}

Produsen otomotif seperti Yamaha, Kawasaki, Suzuki dan merek lainnya harus menyasar konsumen dengan menerapan strategi-strategi bisnis dan memperhatikan faktor merek, desain, harga dan persepsi kualitas sebagai tolak ukur dalam memasarkan produk sehingga dapat memikat niat konsumen untuk membeli produk yang ditawarkan. Dengan meningkatnya perhatian terhadap merek, desain, harga dan persepsi kualitas maka kedepannya pangsa pasar yang di inginkan akan meningkat dari tahun sebelumnya. 


\section{Keterbatasan Penelitian}

Penelitian ini mempunyai keterbatasan, terutama dalam hal lokasi penelitian dan didalam penelitian ini hanya berfokus pada variable merek, desain, harga dan persepsi kualitas yang mempengaruhi niat pembelian sepeda motor di Kota Denpasar, ada baiknya dalam penelitian selanjutnya peneliti dapat mengembangkan variable yang digunakan dan memperluas wilayah penelitiannya. 


\section{DAFTAR PUSTAKA}

Alma, B. (2013). Manajemen Pemasaran dan Pemasaran Jasa. Bandung: Alfabeta.

Agastya M, Albertus. (2015). Pengaruh Desain Produk Terhadap Keputusan Pembelian Produk Sepatu Futsal Specs di Kota Bandung, E-Proceding of Management, 2 (1).

Chu, W., Choi, B., \& Song, M. R. (2005). The Role of On-Line Retailer Brand and Infomediary Reputation in Increasing Consumer Purchase Intention, International Journal of Electronic Commerce.

Crouch, R. C., \& Quester, P. G. (2009). Do consumer expectations match experience? Predicting the influence of price and country of origin on perceptions of product quality. International Business Review.

Darma, G.S. (2006). Mobile Marketing: Sebuah Strategi Keunggulan Bersaing Online. Denpasar: Undiknas Press.

Darma, G.S. (2019). Kacamata Media, Kesuksesan Bersyarat. Indonesia: Pustaka Larasan Press.

Deliza, R. (2010). Studying the influence of package shape and colour on consumer expectations of milk desserts using word association and conjoint analysis. Researchgate.

Fandy, T. (2014). Pemasaran Jasa. Yogyakarta: Andi.

Ferdinand, A. (2002). Structural Equation Modeling dalam Penelitian Manajemen Aplikasi Model-model Rumit dalam Penelitian untuk Tesis Magister \& Disertasi Doktor. Edisi Kedua. Semarang: BP UNDIP.

Ferdinand, A. (2014). Metode Penelitian Manajemen- Pedoman Penelitian untuk Penulisan Skripsi, Tesis, dan Disertasi Ilmu Manajemen, Cetakan Kelima. Semarang: Badan Penerbit Universitas Diponogoro.

Ghozali, I. (2006). Structural Equation Modeling Metode Alternatif dengan Partial Least Square. Semarang: Badan Penerbit UNDIP.

Ghozali, I. (2014). Structural Equation Modeling: Metode Alternatif Dengan PartialLeast Square. Semarang: Badan Penerbit Universitas Diponegoro.

Herlambang, B. (2016). Pengaruh Merek, Desain Dan Harga Terhadap Niat Beli Yang Dimediasi Persepsi Kualitas Produk Sepatu Nike. Universitas Esa Unggul.

Kanten, I.K., and Darma, G.S. (2017). Consumer Behaviour, Marketing Strategy, Customer Satisfaction, and Business Performance, Jurnal Manajemen \& Bisnis, 14 (2): 143-165.

Kotler, P., dan Amstrong, G. (2008). Prinsip-Prinsip Pemasaran Edisi 12. Jakarta: PT. Gelora Aksara Pratama. 
Kotler, P., Amstrong Gary. (2013). Prinsip-prinsip Pemasaran, Edisi ke-12. Erlangga.

Kotler, P. (2012). Marketing Management. Prentice Hall Publication.

Kotler, P., and Kevin Lane Keller. (2016). Marketing Managemen, 15th Edition. Pearson Education, Inc.

Kotler, P., and Keller, Kevin Lane. (2012). Manajemen Pemasaran, Jilid 1, Edisi 13. Erlangga. Kotler, P., and Keller, Kevin Lane. (2013). Manajemen Pemasaran, Jilid 2, Edisi 13. Erlangga. Kriswianti, L. (2017). Pengaruh Kesadaran Merek dan Persepsi Kualitas Terhadap Niat Beli Produk Pelembut Dan Pewangi Pakaian Merek Softener So Klin Twilight Sensation Series di Surabaya Selatan, Jurnal Ilmu Manajemen, B (3).

Kristiyatmoko, Y.W. (2013). Pengaruh Persepsi Kualitas dan Harga Terhadap Minat Beli Tablet Samsung Galaxy Tab, Jurnal Ilmu Management, 1 (2).

Kusnadi, D.S., and Darma, G.S. (2018). Menakar Implementasi Green Marketing Pada Usaha Kecil Menengah, Jurnal Manajemen \& Bisnis, 15 (1): 1-18.

Lee, M., \& Lou, Y. C. (2011). Consumer reliance on intrinsic and extrinsic cues in product evaluations: A conjoint approach, Journal of Applied Business Research.

Maharani, I.G.A.P.D., and Darma, G.S. (2018). Consumer Purchasing Behavior Analysis on Impulse Buying, Jurnal Manajemen \& Bisnis, 15 (3): 16-37.

Mackenzie, L., and Belch. (2006). Journal of Family Ecology and Consumer Sciences, 31.

McCarthy, E.J. (2002). Dasar-Dasar Pemasaran. Jakarta: Erlangga.

Martini, T. (2015). Analisis Pengaruh Harga, Kualitas Produk Dan Desain Terhadap Keputusan Pembelian Kendaraan Bermotor Merek Honda Jenis Skutermatic, Jurnal Penelitian, 9 (1).

Monroe and Krishnan. (2008). Basic Marketing Research. New Jersey: Pearson Education.

Mubarok, D., dan Abdul Aziz. (2016). Pengaruh Celebrity Endorsement Terhadap Minat Beli Konsumen (Studi Pada Konsumen Mahasiswa kelas Reguler Sore STIE INABA Bandung), Jurnal Indonesia Membangun, 3 (1): 1-16.

Mustafid dan Gunawan, Aan. (2008). Jurnal Bisnis dan Manajemen, 4 (2).

Nilforushan, S., \& Haeri, F.A. (2015). The effect of packaging design on customers' perception of food products' quality, value, and brand preference (Case study: Pegah pasteurized cheese, in Isfahan city), WALIA Journal, 31.

Oh, K. (2014). The Effects of Brand, Design, and Price on Intent to Purchase an Activity Tracker. Electronic Theses, Treatises and Dissertations - Florida State University. 
Rao and Monroe. (2008). AMA handbook for customersatisfactiaon: A complete guidance to research planning and implementation, Internasional Edition. Lincolnwood, Illinois, USA: NTC Bussiness Book.

Rindova, V. P., \& Petkova, A. P. (2007). When is a new thing a good thing? Technological change, product form design, and perceptions of value for product innovations. Organization Science.

Rosnani. (2010). Riset Pemasaran dan Perilaku Konsumen. Jakarta: Penerbit PT. Gramedia Pustaka Utama.

Severi, E., dan Ling, Kwek Choon. (2013). The Mediating Effects of Brand Association, Brand Loyalty, Brand Image and Perceived Quality on Brand Equity, Asian Social Science, 9 (3).

Setyawati, T., and Darma, G.S. (2018). Efektifkah Experiential Marketing di Sebuah Rumah Sakit ?, Jurnal Manajemen \& Bisnis, 15 (1): 160-175.

Schoormans, J. P., \& Robben, H. S. (2005). The effect of new package design on product attention, categorization and evaluation, Journal of Economic Psychology.

Sugiyono. (2010). Metode Penelitian Kuantitatif Kualitatif dan R\&D. Bandung: Alfabeta.

Sugiyono. (2012). Memahami Penelitian Kualitatif. Bandung: CV Alphabeta.

Sumarwan, U. (2014). Perilaku Konsumen Teori dan Penerapannya dalam Pemasaran. Bogor: Ghalia Indonesia.

Temporal, P., \& Lee, K. C. (2002). High Touch Branding. Jakarta: Salemba Empat.

Yang, Y. T. (2009). The Impact of Brand Awareness on Consumer Purchase Intention: The Mediating Effect of Perceived Quality and Brand Loyalty, The Journal of International Management Studies, 4.

Yin, S., Wu, L. Du, L., \& Chen, M. (2009) Consumers' purchase intention of organic food in China. Society of Chemical Industry.

Yonus, S., Rasheed, Faiza., dan Zia, Anas. (2015). Identifying the Factors Affecting Customer Purchase Intention, Global Journal of Management and Business Research: A Administration and Management, 15 (2). 